\title{
Searching for Symbolic Value of Cattle: Tropical Livestock Units, Market Price, and Cultural Value of Maasai Livestock
}

\author{
Robert J. Quinlan ${ }^{1,2^{*}}$, Isaya Rumas ${ }^{3}$, Godfrey Naisikye ${ }^{4}$, Marsha B. Quinlan ${ }^{1,2}$, and Jonathan Yoder ${ }^{5,2}$ \\ ${ }^{1}$ Department of Anthropology, Washington State University, Pullman, WA, USA. ${ }^{2}$ Paul G. Allen School for Global Animal \\ Health, Washington State University, Pullman, WA, USA. ${ }^{3}$ Lorboisoit, Simanjiro, Republic of Tanzania. ${ }^{4}$ Terat, Simanjiro, \\ Republic of Tanzania. ${ }^{5}$ School of Economic Sciences, Washington State University, Pullman, WA, USA. \\ rquinlan@wsu.edu
}

\begin{abstract}
We examine metabolic, market, and symbolic values of livestock relative to cultural "positioning" by gender, marriage, and household production among Maasai people in Simanjiro, Tanzania to assess local "proximate currencies" relevant for "cultural success." Data from mixed methods ethnographic research include qualitative interviews since 2012, observation of 85 livestock market sales in 2013 and 2015, and 37 short key informant interviews in 2015. We examine fit between market values, Tropical Livestock Units (TLU, weight-based species exchange ratio), and perceived value from interviews for moran (unmarried men), muruo (married men), and tomonók (married women). Hedonic regression using livestock species, sex, maturity, and size accounted for $90 \%$ of the local market price of livestock. We compared the marketbased exchange ratio between cattle and smallstock (sheep and goats) to TLU and perceived values situating symbolic value of cattle in terms of Maasai household production schema. One TLU model accurately predicted market exchange ratios, while another predicted hypothetical exchanges, suggesting need for improved livestock wealth estimation for pastoralists. Ritual context, subsistence work, and cultural position influenced perceived values: Moran overvalued cattle by $100 \%$ of the local market value. Tomonj́k accurately perceived the market exchange ratio despite never directly engaging in livestock market transactions. Muruo perceived exchange ratios intermediate between moran and tomonj́k. We argue that these perceptions of value reflect distinct labor responsibilities of moran, muruo, and tomonj́k in livestock management, differential value of bridewealth, and control of meat and milk. Attention to value of different livestock species in cultural models of production may prove useful for development efforts.
\end{abstract}

Received January 28, 2016

OPEN ठACCESS

Accepted September 1, 2016

DOI 10.14237/ebl.7.1.2016.621

Keywords Ethnozoology, East Africa, Smallholder household wealth, Pastoralism, Gender and marriage, Ethnographic science

Copyright (c) 2016 by the author(s); licensee Society of Ethnobiology. This is an open-access article distributed under the terms of the Creative Commons Attribution-NonCommercial 4.0 International Public License (https://creativecommons.org/licenses/by-nc/4.0), which permits non-commercial use, distribution, and reproduction in any medium, provided the original author and source are credited.

African pastoralist people love their animals, and this bond has shaped their cultural practice for at least a millennium (Herskovitz 1926). Today pastoralist lives are transforming with different livestock use and value (Fratkin 2001, 1991; Galvin 2009). Maasai people of Northern Tanzania offer one model of East African pastoralism, and they are the focus of our account. This research was motivated by a simple, nagging, and unresolved question in human behavioral ecology: How do people value local "proximate currencies" for "cultural success" (Irons 1998)? Everywhere people place value on things that are particularly relevant for success in that environment. In human behavioral ecology assets are "proximate currencies" which are crucial for understanding adaptively relevant decisions in context. Yet we know little about how assets come to have a particular value locally. Ecological and economic anthropologists focusing on pastoralism routinely convert livestock assets into a unidimensional measure of wealth in kilograms of meat known as Tropical Livestock Units. In many accounts of pastoralists, however-and in their own words-cattle are the "gold standard" valued above other livestock (e.g., sheep, goats, camels). We explore the cultural context of livestock valuation among Simanjiro Maasai. We begin with an ideal account of the role of livestock in ritual and in the division of labor. We examine market value of 
livestock which we use to assess equivalence of cattle and small-stock (sheep and goats) compared with common weight-based exchange ratios for tropical livestock. Finally, we report variation in a hypothetical exchange among Maasai in different cultural positions relevant to household production.

Livestock are the assets that Maasai people control to help ensure their wellbeing, which depends on converging and diverging individual and group motivations. Livestock valuation, hence, depends on one's "positioning" (sensu Hodgson 2011) within Maasai society and in broader contexts. Herds form the base of Maasai livelihood. Birth, daily chores, division of labor, and rituals of maturation and marriage revolve around livestock. Livestock provide people milk and meat. Herds are "savings accounts" and animals are the medium of exchange connecting people to each other in the homestead or nkang, across homesteads and regions through stock partnerships or pakishu, and into global systems through cash sales. We approach the value of animals from four vantage points: (1) How do they contribute to diet? Or what is the metabolic value of livestock? (2) How do people convert them into other resources through currency? Or what is their market value? (3) What is their value beyond these materialist perspectives? Or what is their symbolic value? (4) How might we translate livestock values across these perspectives?

Maasai people engage in a range of livelihoods, but livestock are at the center of traditional subsistence and transitional, mixed household economies. A series of "binary oppositions" (Turner 1973) concerning pastoralist household production guides our analysis. Meat:milk, cattle:smallstock, man:woman, adult:juvenile, married:moran (warriors) characterize important dimensions of ritual, life history, and livelihood. These oppositions reflect traditional cultural models of household production and provide "predictor variables" for local diversity in estimating the value of livestock.

Our account draws on direct observation and interviews among Maasai people in Simanjiro District, Northern Tanzania (2012-present). Simanjiro Maasai live along an economic continuum from subsistencelevel herding and agriculture to intensive cash cropping. Extended family homesteads or nkang are the units of production and corrals for livestock when animals are not traveling with moran in search of grazing and water. For recent accounts of Simanjiro

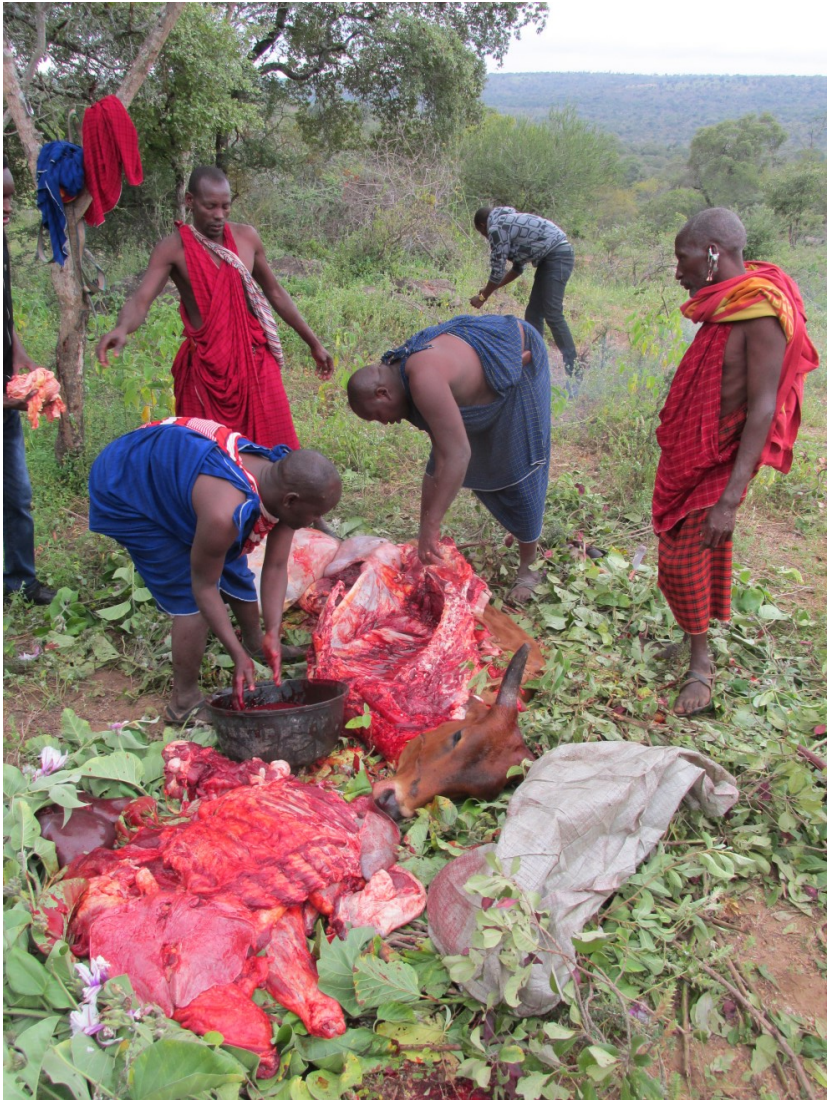

Figure 1 Men's tree. Photo: Robert J. Quinlan, 2015.

Maasai see Leslie and McCabe (2013), McCabe et al. (2014), Miller et al. (2014), and Sachedina and Trench (2009).

Marital status and gender are two key characteristics of Maasai social organization for household production. Marriage marks a transition in life for both genders through different pathways. For women, marriage traditionally (and often still) takes place soon after menarche. A woman transitions from a girl through ritual observances including now outlawed circumcision, and menstrual taboos. Menarche relates to livestock by marking the onset of taboos prohibiting women from slaughtering animals or even seeing meat before it is delivered to them from the men's tree outside the nkang fence where butchering often occurs (Figure 1). Mere presence of a menstruating woman could taint the meat (Montgomery 1974; Nichter and Nichter 1996). Boys and girls act as messengers, bringing meat from the men's tree to their mothers for the family cooking pot. Men control the distribution of meat. 
When a new wife arrives at her husband's nkang for the first time not long after menarche, an older cowife or mother-in-law meets her at the nkang entrance with a gift: a milk cow. Her husband allocates a herd of milk cows to his wife who is responsible for managing the animals-milking twice a day, watching for illness, etc. This dairy herd will become the basis of the woman's sons' herd, along with other gifts, when he/they reach marriageable age near the end of the moran period (Hodgson 2001). The animals are never technically a woman's property in that she could not buy, sell, or slaughter them without her husband's consent. Still, she manages their health and productivity, and with their milk she cares for herself, her children, her husband, and friends. In the nkang women control the milk (Figure 2).
When a woman gives birth, her husband celebrates the occasion and cares for her by giving her one ram with large fat flaps around the base of the tail. A mature sheep's fat flap looks like a wooly throw pillow and can weigh ten pounds. Tail fat should be a mother's first meal after delivery. Thereafter, the grease and greasy meat enhances the mother's milk production and recovery from birth over a period of rest when she may not work. By convention, a man can obtain a birth ram by exchanging one young, small steer with an exchange partner. This is an important point because the convention specifies the exchange ratio of sheep to cattle that we use to explore symbolic value.

Women can convert the products of their work into cash. They sell surplus milk, butter, eggs, chickens, beadwork, gourds, etc. at local markets or to

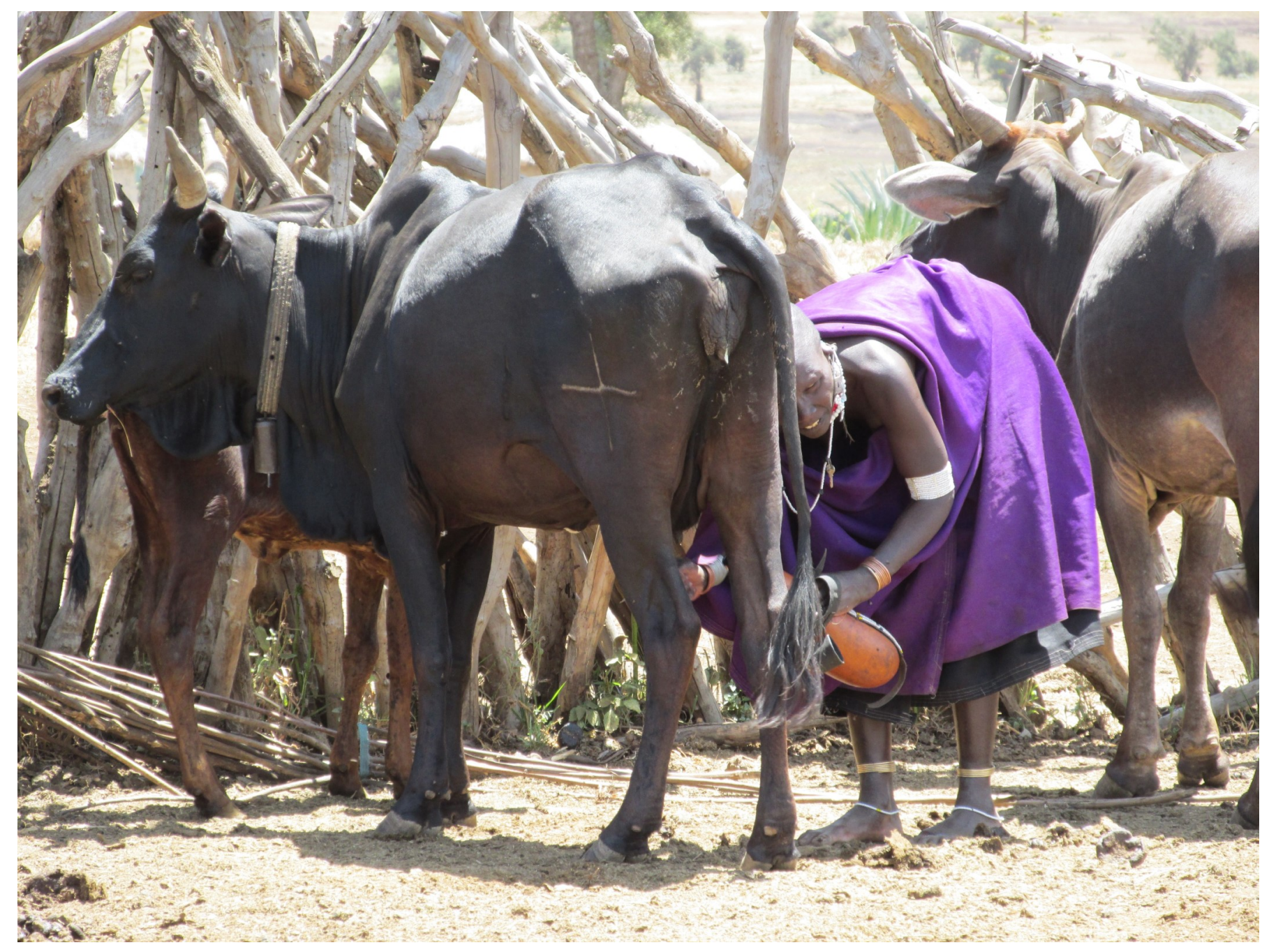

Figure 2 Milking a cow. Photo: Robert J. Quinlan, 2013. 


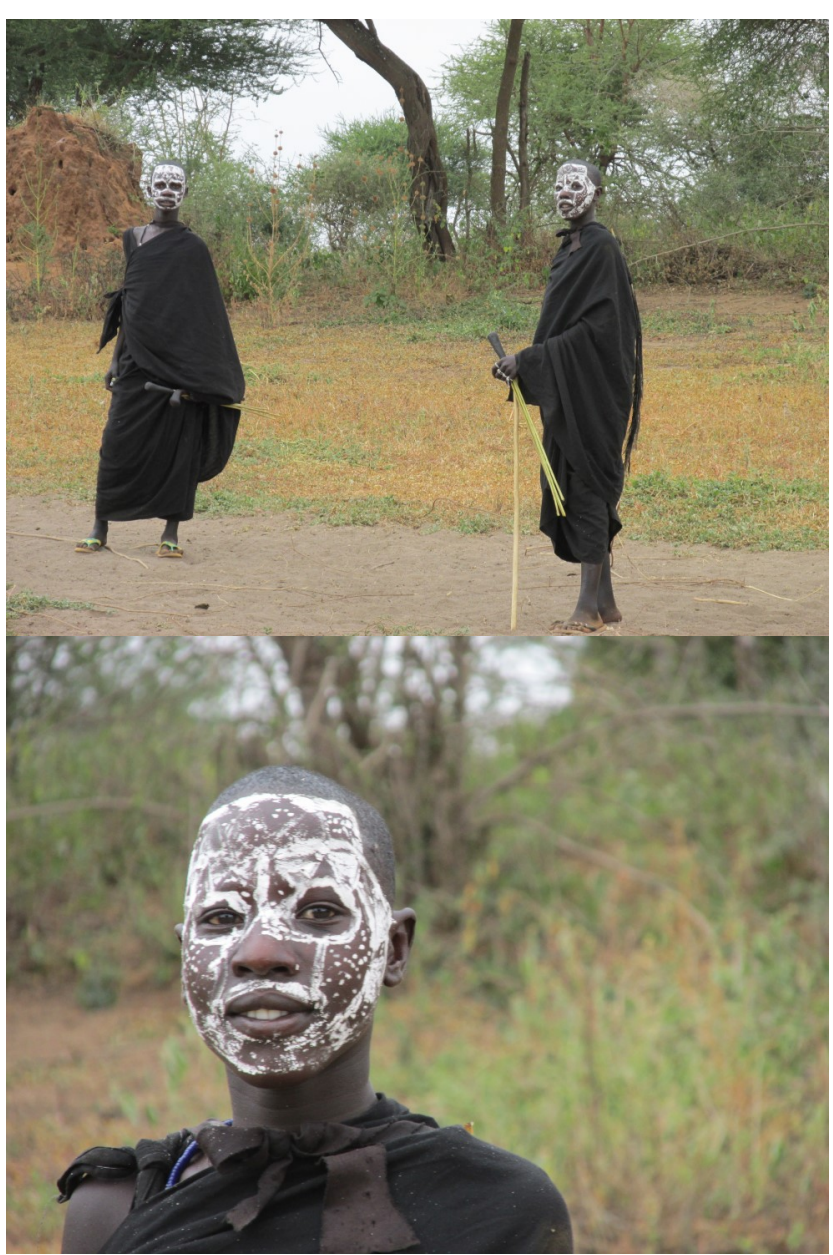

Figure 3 New moran in circumcision paint. Photo: Robert J. Quinlan, 2015.

visitors to the nkang (Hodgson 2001). They use that cash for children's school expenses, cellphones, tools, and to sometimes purchase small stock (sheep and goats) that are the woman's assets or savings. Women have other assets: They build their houses without help from men, they own donkeys to haul water and firewood, and they have cell phones, cooking pots, gourds, etc.

For men the transition to marriage is much less abrupt. At about 15 to 17 years old a boy undergoes circumcision (Figure 3). Transfer of livestock marks this event too: Guests to the circumcision feast bring one or two smallstock for the host. At this ritual, boys become moran and must give up the only animal property they have had: their dogs. They spend the next 15 or so years (it varies from person to person) caring for and protecting livestock, often in distant dry season manyatta or cattle camps.
Men transition from moran into moruo, or elders, through marriage, again entailing ritual transfer of cattle for bridewealth. New grooms receive a share of their father's herd along with gifts from friends and relatives and make bridewealth payments minimally of five steers to their bride's father. The amount can vary somewhat depending on the balance of wealth between the groom's and bride's families. Older men slaughter three of the bridewealth animals for the wedding feast, and may distribute other animals to kin or friends of the bride's father. After marriage, a man takes responsibility for the production of his household, often in coordination with close kin who reside near him in the patrilocal nkang.

After marriage, a man uses his herd to provide milk cows for his wives to manage; for meat consumption largely for men, although a portion goes to the household as described above; and for creating and maintaining stock-partner or pakishu relationships. Stock partner relationships are an important part of herd management in dry years and in response to livestock loss through disease and drought (Aktipis et al. 2011). In dry years, when grazing is difficult, morno reach out to pakishu in distant communities (often by cell phone) to find good grazing and to negotiate moving their herd into land associated with other communities. When times are tough or the family needs cash, men sell livestock in local markets.

Smallstock are the most disposable form of livestock wealth. Wealthy households slaughter sheep and goats to meet regular protein desires, and any household may sell them off for cash. In comparison, selling cattle is undesirable and Maasai generally view it as a last resort, though some households appear to somewhat specialize in cattle production for sale (Caudell et al. n.d.). When Nadonjukin moruo decide to sell livestock, they usually travel to the weekly local market in Terat town. Women also sell their wares in local markets, but we never saw women directly engaged in negotiations in 85 livestock transactions observed in Terat market.

We can simply use any of several unidimensional metabolic equivalence models for livestock known as Tropical Livestock Units (TLU), where smallstock and cattle are evaluated by "package weight", but this assumes that the only relevant currency for local success is food. In an early TLU model, one "cow" Bos indicus $(B \imath)$ is assumed to weigh $175 \mathrm{~kg}$, and one sheep or goat weighs $25 \mathrm{~kg}$ giving an exchange ratio of seven cattle to one sheep or goat (Jahnke 1982). A 
more common TLU model, cited in Grandin (1988), gives an exchange ratio of 4.17 to one. We can thus convert a herd of mixed composition into a measure of "non-monetized wealth". Does this make sense for Maasai livestock? We could approach the question at least two ways: (1) Do Maasai cattle, on average, weigh seven times a sheep or goat? The answer suggests a better local measure of "livestock value" but it assumes that all wealth translates into kilograms of meat or milk. A biomass approach requires good methods for estimating weight and milk production in the field and time to measure a sufficiently large sample of herds of different composition and intended use. This is a reasonable approach, but differences in control of meat and milk from cattle and smallstock suggests an alternative. (2) What is the local "exchange ratio" of one livestock species for another? Do Maasai people of different positions in the production system value livestock differently?

\section{Market Price of Maasai Livestock and TLUs}

We examined market price to evaluate the adequacy of TLU estimates and to examine discrepancies in hypothetical exchanges that might indicate effects of cultural positioning in the production system. The research team observed 85 livestock transactions on two market days in Terat in October 2013 and June 2015. RQ's and MQ's presence as observers immediately destabilized price negotiations, and they did not observe transactions closely. Instead IR and GN, both Maasai muruo members of the research team, with extensive experience in research and livestock management recorded the asking price, sale price, species, sex, age (juvenile or adult), and relative size (relatively small, "average", relatively large). Livestock markets seem chaotic with negotiations occurring ad lib. Hence, we selected a convenience sample of as many transactions as possible. With these data we converted sales price of cattle into smallstock to examine fit between TLU estimates and local market value. Later we use market price to estimate the "symbolic" value of cattle for people in different "positions." Ironically, this approach allows us to "monetize" symbolic value (transform it into cash value) to examine intra-cultural variation reflecting convergent and divergent interests in herd management.

Men bring livestock on a lead into the market square beginning in the late morning of market day. Transactions occurred in public and men negotiated prices verbally, often with many onlookers, including women and children. The owner began negotiations with an asking price, the buyer countered, etc. Table 1 summarizes 85 market transactions for individual animals in Terat. The average transaction was TSh 156,482 (Tanzanian Shillings) or approximately US\$82. Average price received for cattle was TSh 285,972 or US $\$ 150$. Average price for sheep and goats

Table 1 Terat market livestock transactions.

\begin{tabular}{|c|c|c|c|c|c|c|c|c|}
\hline \multicolumn{2}{|c|}{ All transactions } & \multirow{2}{*}{$\begin{array}{l}\mathbf{N} \\
85\end{array}$} & \multirow{2}{*}{$\begin{array}{l}\text { Mean } \\
156482\end{array}$} & \multirow{2}{*}{$\begin{array}{l}\text { SD } \\
126163\end{array}$} & \multirow{2}{*}{$\begin{array}{l}\text { Min } \\
20000\end{array}$} & \multirow{2}{*}{\begin{tabular}{|l|} 
Max \\
550000
\end{tabular}} & \multicolumn{2}{|c|}{$95 \% \mathrm{Cl}$} \\
\hline Livestock & Receive & & & & & & 129270 & 183695 \\
\hline & Adult & 86 & 0.53 & & 0 & 1 & & \\
\hline & Size & 86 & 2.12 & & 1 & 3 & & \\
\hline & Male & 86 & 0.64 & & 0 & 1 & & \\
\hline \multirow[t]{4}{*}{ Cattle } & Receive & 36 & 285972 & 85003 & 130000 & 550000 & 257212 & 314733 \\
\hline & Adult & 36 & 0.36 & & 0 & 1 & & \\
\hline & Size & 36 & 2.00 & & 1 & 3 & & \\
\hline & Male & 36 & 0.67 & & 0 & 1 & & \\
\hline \multirow[t]{4}{*}{ Sheep } & Receive & 25 & 64920 & 27494 & 25000 & 110000 & 53571 & 76269 \\
\hline & Adult & 25 & 0.68 & & 0 & 1 & & \\
\hline & Size & 25 & 2.40 & & 1 & 3 & & \\
\hline & Male & 25 & 0.68 & & 0 & 1 & & \\
\hline \multirow[t]{4}{*}{ Goats } & Receive & 24 & 57625 & 28147 & 20000 & 120000 & 45740 & 69510 \\
\hline & Adult & 25 & 0.64 & & 0 & 1 & & \\
\hline & Size & 25 & 2.02 & & 1 & 3 & & \\
\hline & Male & 25 & 0.56 & & 0 & 1 & & \\
\hline
\end{tabular}

Note: Receive = Tanzania Shillings; adult (animal) 1 = adult, $0=$ juvenile; size $1=$ relatively small; $2=$ about average; $3=$ relatively large; male 1 = male, 0 = female. 
was TSh 64,920 and TSh 57,625 respectively or US $\$ 34$ and US $\$ 30$. Because the price difference between sheep and goats was not statistically significant, we pooled their values in these analyses. Here, one $B i$ is equivalent to 4.67 smallstock in the market. TLU gives an exchange ratio of 7.00 smallstock for one $B i$ as reported in Jahnke (1982) and about 4.2 smallstock for on $B i$ reported in Grandin (1988). Early TLU exchange ratios (Jahnke 1982) overestimate the value of cattle or underestimate smallstock in our market sample. Exchange ratios from Grandin (1988) give a better estimate of Simanjiro livestock equivalence based on market prices. Depending on context, however, livestock value might not be entirely metabolic or nutritional. Providing a fat-tail ram at birth could be more than nutritional provisioning.

\section{Using Market Price to Estimate Symbolic Value of Maasai Livestock}

Next we constructed a multivariate model called a hedonic regression (Coatney et al. 1996; Lankester et al. 2015; Rosen 1974) to evaluate determinants of market price used to suggest the symbolic value of a fat-tail ram. Here we regressed price received on species (sheep or goat $=1$ with $B i=0$ as the reference), sex (male $=1$, female $=0)$, adult $(1=$ adult, $0=$ juvenile $)$, size $(1=$ small to $3=$ large $)$, and interaction effects for species X size. Because we did not weigh animals, species $\mathrm{X}$ size adjusts for the weight difference between a small vs large goat and a small vs large steer. We also entered year of sale (2013 vs 2015) to adjust for inflation and market volatility. Size and age were centered so that we could interpret model constants as the price for an average animal. Diagnostic tests indicated an adequate model.
The model in Table 2 accounts for $90 \%$ of the variance in market price. Using this equation, we calculated the predicted value of average adult smallstock and average adult cattle at TSh 68,373 and TSh 318,466 respectively which gives an exchange of 4.66 smallstock for one Bi compared with 4.67 (Table 1). With this model, we calculate the value of a large ram and a small steer to evaluate the symbolic value of a birth ram. Using the regression equation, a fat ram is worth TSh 92,642 and a small steer is worth TSh 174,763 putting the market exchange ratio at 1.89 fat rams to one small steer. The extent that the ritual value of a ram is greater than its market value suggests symbolic value of birth provisioning. Hence, the symbolic value of a fat ram as birth provisioning is the difference between the traditionally specified 1:1 exchange ratio and the market exchange ratio 1:1.89 or TSh 82,120 (approximately US\$43). For some people in a specific marriage-gender position, a small steer is not worth 1.89 fat rams, but one fat ram. Ritual context influences the perceived value of Maasai livestock.

Hypothetical Exchange of Smallstock for Cattle by Marriage and Gender Positions

If ritual context can alter the perceived value of livestock, then what about other dimensions of "positioning" in Maasai cultural ecology? Supplied with knowledge of the local market value of livestock, we then examined perceptions of smallstock and cattle values with a hypothetical exchange. During the course of qualitative livestock management interviews we were impressed with the variation in responses and the large discrepancies between a hypothetical exchange and market values. We recruited a convenience sample of 37 Maasai people and posed two questions to them: 1) How many average smallstock

Table 2 Hedonic model of market price.

\begin{tabular}{lllll}
\hline TSh Received & Coef. & $\mathbf{P}$ & \multicolumn{2}{c}{$\mathbf{9 5 \%} \mathbf{C l}$} \\
\hline Sheep & -252018 & 0.000 & -275559 & -228478 \\
Size (centered) & 100655 & 0.000 & 69514 & 131796 \\
Sheep X Size & -84831 & 0.000 & -124277 & -45386 \\
Goat & -251572 & 0.000 & -274690 & -228455 \\
Goat X Size & -84658 & 0.000 & -121918 & -47397 \\
Adult (centered) & 44677 & 0.000 & 20882 & 68473 \\
Sex (male=1, female=0) & 10962 & 0.311 & -10460 & 32383 \\
Year (centered) & 1975 & 0.716 & -8793 & 12742 \\
Constant & 298789 & 0.000 & 279350 & 318228 \\
\hline
\end{tabular}

Note: $\mathrm{R}^{2}=.90$ 
Table 3 Sample for hypothetical exchange of livestock.

\begin{tabular}{llllll}
\hline Variable & N & Mean & SD & Min & Max \\
\hline Steer & 37 & 8.88 & 5.32 & 3.5 & 30 \\
Cow & 37 & 6.88 & 2.57 & 4 & 16 \\
Cattle & 37 & 7.88 & 3.63 & 3.75 & 20 \\
Moran & 37 & 0.35 & 0.48 & 0 & 1 \\
Adult Male & 37 & 0.35 & 0.48 & 0 & 1 \\
Women & 37 & 0.30 & 0.46 & 0 & 1 \\
\hline
\end{tabular}

would be fair in exchange for one average cow? And 2) how many average smallstock would be fair in exchange for one average steer? Hypothetical exchange questions were asked in public with onlookers out of earshot to reduce contamination. Informants were compensated with a payment of TSh 1000 (approximately US\$0.50). An average interview was completed in less than five minutes. We recorded the gender and marital status of the informants; hence, we have three groups-married women or tomonśk, married men or móruo, and unmarried men or moran (Table 3). The mean hypothetical exchange rate for cattle is 7.88 smallstock or 3.2 goats-sheep more than the market value based on data in Table 4. Note this figure is close to TLU exchange ratios in Jahnke (1982). Does this value vary, however, by gender and life history?

Women's average hypothetical value of one $B i$ was between about four and eight smallstock (see 95\% CI for constant model 1, Table 4), which is not significantly different from the observed market value and overlaps with TLU estimates. Husbands (móruak) are not significantly different compared with wives.
Moran, however, valued one $B i$ at about ten smallstock, which was more than twice the market value. There were no significant differences among Maasai for the value of cows (i.e., female $B$ i): They perceived cows to be worth between the market value and TLU estimates. Market prices indicated that male and female livestock had equal monetary value, and women agreed. In the hypothetical exchange, men significantly overvalued steers relative to women. Moran "overvalued" steers by more than three times their local market value, with a ratio of 13:1 (Table 4, model 3 adding the constant and coefficient for moran). Using market prices (from Table 2) and the same procedure for the analysis of birth provisioning, we calculated the difference between the hypothetical exchange and market exchange ratio to indicate symbolic value of cattle for men. The "symbolic value" of each steer for a morani was about 8.5 smallstock more than the market value, about TSh 400,000 or US $\$ 200$. For married men the symbolic value of steers was less than for moran but, at TSh 140,000 or US $\$ 75$, it was significantly greater than women value steers relative to cows, and more than

Table 4 Multivariate model of hypothetical exchange of smallstock for cattle by animal sex, human gender, and marriage.

\begin{tabular}{lllllll}
\hline $\begin{array}{l}\text { Dependent Variable: } \\
\text { Smallstock for Cattle }\end{array}$ & $\mathbf{R}^{\mathbf{2}}$ & Position & Coef. & $\mathbf{p}$ & & $\mathbf{9 5 \%} \mathbf{C l}$ \\
\hline Mod. 1 & \multirow{2}{*}{0.31} & Moruo & 1.08 & 0.402 & -1.50 & 3.66 \\
Cattle & Moran & 4.66 & 0.001 & 2.07 & 7.24 \\
& & Constant & 5.86 & 0.000 & 3.96 & 7.76 \\
\hline Mod. 2 & Moruo & -0.04 & 0.967 & -2.12 & 2.03 \\
Cow & \multirow{2}{*}{0.11} & Moran & 1.77 & 0.093 & -0.31 & 3.84 \\
& & Constant & 6.27 & 0.000 & 4.75 & 7.80 \\
\hline Mod. 3 & \multirow{2}{*}{0.36} & Moruo & 2.20 & 0.227 & -1.44 & 5.84 \\
Steer & & Moran & 7.55 & 0.000 & 3.91 & 11.18 \\
& & Constant & 5.45 & 0.000 & 2.78 & 8.13 \\
\hline Mod. 4 & \multirow{2}{*}{0.35} & Moruo & 0.38 & 0.044 & 0.01 & 0.74 \\
Steer/Cow & Moran & 0.77 & 0.000 & 0.41 & 1.13 \\
& & Constant & 0.89 & 0.000 & 0.62 & 1.16 \\
\hline
\end{tabular}

Note: Constant indicates women's hypothetical exchange: Muruo and Moran values are in addition to the constant. 


\section{(f) Ethnobiolocy Letters

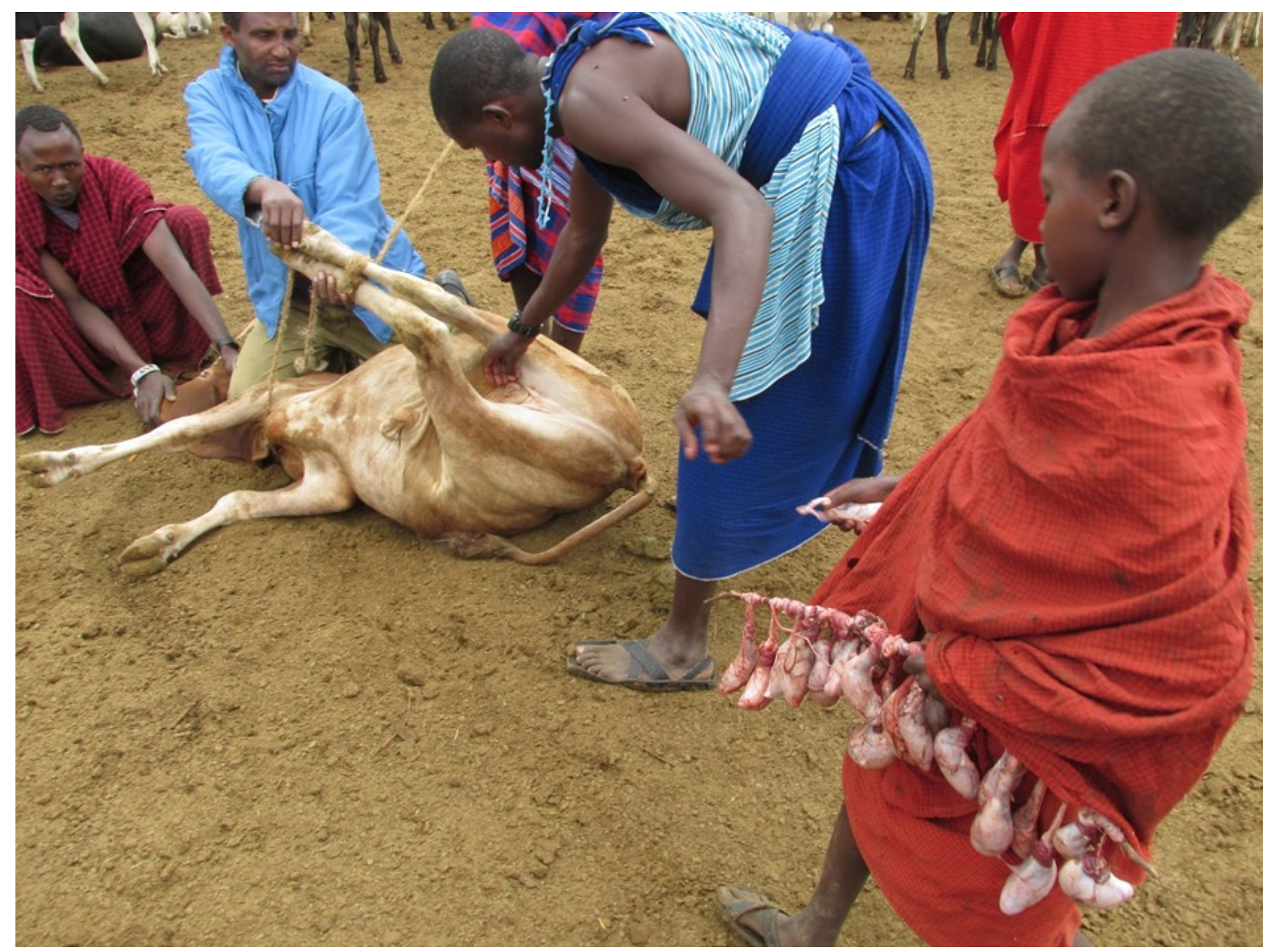

Figure 4 Castrating steers. Photo: Robert J. Quinlan, 2015.

the market would pay. Hence, women's perception of livestock values concurred with the market; men's perception did not because they overvalue steers.

\section{Translating Exchange Ratios}

As a measure of total livestock wealth, TLU estimates appear to be reasonable approximations, but livestock equivalence varies by gender and ritual context. For men and particularly moran, TLU and market exchange ratios undervalue steers.

What good is a steer to whom as they do not reproduce, nor produce milk, and they require time, attention, water, food, medicine etc.? People have to make a steer by castration (Figure 4). Steers are useful as special meat. If access to meat from steers varies by one's cultural positioning, then their value may vary accordingly. However, cattle and smallstock meat should be equivalent pound-for-pound, hence, moran's overvaluation can be interpreted as symbolic value. Clues for understanding this symbolic value may be in ritual consumption of beef mixed with medicinal plants for cleansing in orpul (Figure 5) (Roulette et al. n.d.).

Additionally, moran are often responsible for managing steers that are not a part of the nkang milk herd. Moran status among peers and within their family is related to their responsibility for the "grazing" herd which typically includes fewer milk cows than does the nkang herd; thus steers could carry special significance for Moran. Alternatively, cattle may be valued as more desirable bridewealth, and hence, represent more value for young men anticipating marriage. Moran overvaluation of steers might be interpreted as symbolic value in relation to their role in the production and marriage systems. 


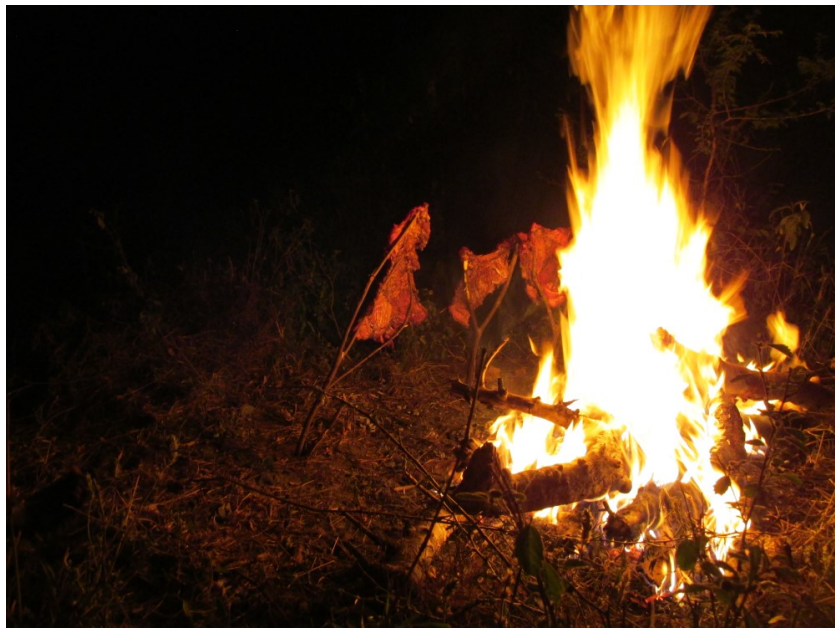

Figure 5 Beef for orpul. Photo: Robert J. Quinlan, 2015.

\section{Conclusions}

Symbolic value of subsistence assets is difficult to operationalize because it is a function of multiple considerations for individuals in historical and social context. Drawing on human behavioral ecology we conceptualize symbolic value as part of local proximate currencies that tap into aspects of "adaptively relevant environments" (Irons 1998). We suggest as a starting point for integrated economic, ecological, and cultural analysis that symbolic value is the value of an asset beyond subsistence or cash equivalent of food value. For Simanjiro TLU estimates from Grandin (1988) are close to local market value suggesting that market prices track nutritional value of animals pound for pound. We suggest that comparing local conventions for ritual exchange of livestock for a birth gift with market values serves as a proxy for symbolic value. Moran over-valuation of steers is perhaps less clearly a reflection of symbolic value and we welcome alternative critiques. Here we suspect that moran (and married men's) valuation of steers reflects (1) the role that beef plays in social solidarity among men, (2) the role of cattle in bridewealth exchanges, and (3) value of stock-partner exchange relationships for risk reduction. The latter may be less symbolic (closer to subsistence, survival and reproduction) as stockpartners provide a kind of insurance against local variance in forage and water (Aktipis et al. 2011).

Our results suggest several points for development. Different species have different uses. Cattle provide daily milk and special meat largely reserved for ritual purposes. Selling cattle is undesirable. In contrast, few Maasai regularly drink or sell milk from smallstock and many people have never tasted it.
Smallstock are the source of meat for regular household consumption, and smallstock sales are common to provide for cash needs. This difference suggests potentially important avenues for gendered development. For example, the Maasai Foundation (directed by co-author, Isaya Rumas) takes advantage of the cultural position of smallstock to help women develop their own smallstock herds. The foundation converts homemade crafts into cash to purchase animals which reproduce, giving potentially large returns on women's crafts and animal husbandry.

Division of labor in milk and meat handling can also influence public health and disease transmission. Cultural models for meat handling exposes men to meat-borne pathogens similar to gendered funerary practices in Mathews, Glasse and Lindenbaum's (1968) classic study of kuru retrovirus transmission. Similarly, preliminary results for prevalence of antibiotic resistant bacteria among Maasai suggest that cows' milk is involved in transmission of resistant bacteria (Call et al. 2016). The precise mechanism for this transmission is unknown at present, but milk handling is a likely suspect making these patterns targets for public health engagement.

Greater attention to relative value and role of different livestock species in cultural models of production may prove useful for development efforts. We hope this short study of livestock values offers a contribution for collaborative work to enhance the wellbeing of African pastoralist people.

\section{Acknowledgments}

This work was funded through a grant from the U.S. National Science Foundation, Ecology and Evolution of Infectious Disease Program \#DEB-1216040 (D.R. Call et al.). Thanks to the people of Nadonjukin Village and Terat Town for their generous cooperation in this research. Thanks to Dr. Julius Keyuu, Tanzania Wildlife Research Institute for facilitating our larger collaborative research efforts in Tanzania. Special thanks to Dr. Doug Call of the Washington State University, Paul G. Allen School for Global Animal Health for his collaborative spirit and able leadership of our larger interdisciplinary efforts in Tanzania.

\section{Declarations}

Permissions: Washington State University Institutional Review Board; Tanzania National Institute for Medical Research Review Board; Tanzania Commission on Science and Technology Permit. Local 
Permission from Nadonjukin Village Council, Simanjiro, Tanzania.

Sources of Funding: National Science Foundation, NSF DEB-1216040 (D. Call et al.).

Conflicts of Interest: None declared.

\section{References Cited}

Aktipis, C. A., L. Cronk, R. de Aduiar. 2011. Risk Pooling and Herd Survival: An Agent Based Model of a Maasai Gift Giving System. Human Ecology 39:131-140. DOI:10.1007/s10745-010-9364-9.

Call, D. R., M. Subbiah, M. Caudell, L. Orfe, R. J. Quinlan, M. B. Quinlan, L. Matthews, and C. Mair. 2016. Consumption of Raw-milk: A Critical Risk Factor in Disseminating Antibiotic-resistant Bacteria to Maasai People in Northern Tanzania. Unpublished data. Available from drcall.vetmed@wsu.edu.

Caudell, M., M.B. Quinlan, M. Subbiah, D. R. Call, C. J. Roulette, J. W. Roulette, A. Roth, L. Mathews, R. J. Quinlan. n.d. Veterinary Antibiotic Use among Agro-Pastoralists in Northern Tanzania. Unpublished manuscript. Available from drcall.vetmed@wsu.edu.

Coatney, K. T., D. J. Menkhaus, and J. D. Schmitz. 1996. Feeder Cattle Price Determinants: An Hedonic System of Equations Approach. Review of Agricultural Economics 18:193-211. Available at: http://www.jstor.org/stable/1349432? seq=1\#page_scan_tab_contents. Accessed on January 28, 2016.

Fratkin, E., and E. A. Roth. 1990. Drought and Economic Differentiation among Ariaal Pastoralists of Kenya. Human Ecology 18:385-402.

Fratkin, E. 2001. East African Pastoralism in Transition: Maasai, Boran and Rendille Cases. African Studies Review 44(3):1-25. Available at: http:// www.jstor.org/stable/525591? seq=1\#page_scan_tab_contents. Accessed January 28, 2016.

Galvin, K.A. 2009. Transitions: Pastoralists Living with Change. Annual Review of Anthropology 38:18598. DOI:10.1146/annurev-anthro-091908-164442.

Herskovitz, M. J. 1926. The Cattle Complex in East Africa. American Anthropologist 28(1):230-272. Available at: http://www.jstor.org/stable/ pdf/660813.pdf. Accessed January 28, 2016.

Irons, W. 1998. Adaptively Relevant Environments
Versus the Environment of Evolutionary Adaptedness. Evolutionary Anthropology 6:194-204.

DOI:10.1002/(SICI)1520-6505(1998)6:6<194::AIDEVAN2>3.0.CO;2-B.

Grandin, B.E. 1988. Wealth and Pastoral Dairy Production: A Case Study from Maasailand. Human Ecology 16:1-21.

Hodgson, D. 2001. Once Intrepid Warriors. Indiana University Press, Bloomington, IN.

Hodgson, D. 2011. Being Maasai, Becoming Indigenous. Indiana University Press, Bloomington, IN.

Jahnke, H. E. 1982. Livestock Production Systems and Livestock Development in Tropical Africa. Kieler Wissenshfstverlag Vauk, Kiel, Germany. Available at: http://pdf.usaid.gov/pdf_docs/pnaan484.pdf. Accessed January 28, 2016.

Lankester F, A. Lugelo, R. Kazwala. J. Keyyu, S. Cleaveland, and J. Yoder. 2015. The Economic Impact of Malignant Catarrhal Fever on Pastoralist Livelihoods. PLoSONE 10:e0116059. DOI:10.1371/ journal.pone.0116059.

Leslie, P. W., and J. T. McCabe. 2013. Response Diversity and Resilience in Social-Ecological Systems. Current Anthropology 54:114-143. DOI:10.1086/669563.

Mathews, J. D., R. Glasse, and S. Lindenbaum. 1968. Kuru and Canibalism. The Lancet 292:449-452. DOI:http://dx.doi.org/10.1016/S0140-6736(68) 90482-0.

McCabe, J. T., N. M. Smith, P. W. Leslie, and A. L. Telligman. 2014. Livelihood Diversification through Migration among a Pastoral People: Contrasting Case Studies of Maasai in Northern Tanzania. Human Organization 73:389-400. Available at: http:// www.ncbi.nlm.nih.gov/pmc/articles/ PMC4347807/. Accessed January 28, 2016.

Miller, B. W., P. W. Leslie, and J. T. McCabe. 2014. Coping with Natural Hazards in a Conservation Context: Resource-Use Decision of Maasai Households during Recent Historical Droughts. Human Ecology 42:753-768. DOI 10.1007/s10745-014-96833.

Rosen, S. 1974. Hedonic Prices and Implicit Markets. The Journal of Political Economy 82:34-55. Available at: http://www.jstor.org/stable/1830899? seq=1\#page_scan_tab_contents. Accessed January 28, 2016. 
Roulette, C. J., E. F. Njau, M. B. Quinlan, R. J. Quinlan, and D. Call. N.D. Maasai Dietary Additives in Tanzania: Ethnomedical Beliefs, Ethnopharmacology, and Gender Differences. Unpublished manuscript. Available from croulette@sdsu.edu.

Sachedina, H., and P. C. Trench. 2009. Cattle, Crops, Tourism and Tanzanite: Poverty, Land Use Change, and Conservation in Simanjiro District, Tanzania. In
Staying Maasai?, edited by K. Homewood, P. Kristjanson, and P. C. Trench. Springer-Verlag, New York, NY.

Turner, V. W. 1973. Symbols in African Ritual. Science 179:1100-1105. Available at: https://

www.amherst.edu/system/files/media/1479/

Symbols\%2520in\%2520African\%2520Ritual_0.pdf. Accessed February 24, 2016. 